\title{
Characterization of antimicrobial activity of culturable bacteria isolated from Krubera-Voronja Cave
}

\author{
Aiste Klusaite ${ }^{1}$, Vida Vickackaite ${ }^{2}$, Birute Vaitkeviciene ${ }^{3}$, Rasa Karnickaite ${ }^{3}$, \\ Dominykas Bukelskis $^{1}$, Ieva Kieraite-Aleksandrova ${ }^{1}$, and Nomeda Kuisiene ${ }^{1^{*}}$ \\ ${ }^{1}$ Department of Microbiology and Biotechnology, Life Sciences Center, Vilnius University, Sauletekio avenue 7, LT-10257, Vilnius, Lithuania \\ ${ }^{2}$ Department of Analytical and Environmental Chemistry, Faculty of Chemistry, Vilnius University, Naugarduko 24, LT-03225, Vilnius, Lithuania \\ 3JSB "Labtarna", Kauno 1A, LT-01314, Vilnius, Lithuania
}

\begin{abstract}
In the present study we aimed to perform the first analysis of antimicrobial activity of bacteria isolated from Krubera-Voronja Cave, with the main focus on their activity against Grampositive bacteria, including Gram-positive pathogens. Using five different media, in total 874 heterotrophic cultures were isolated from water and sediment samples collected in Krubera-Voronja Cave at a depth from $220 \mathrm{~m}$ to $1640 \mathrm{~m} .14 .0 \%$ of all isolates demonstrated antibacterial activity against Gram-positive and Gram-negative test microorganisms. Our results show that this percentage was not uniform; it increased with the sampling depth and was the highest in the lower part of the cave. 24 isolates were active exclusively against Gram-positive test strains Micrococcus luteus and Bacillus thuringiensis. Two isolates, namely strains 1350R2-TSA30-6 and 1410WF1-TSA30-2, were chosen for the further work because of the high and comparable activity against both Gram-positive test microorganisms. It was determined that both strains belong to the family Bacillaceae in phylum Firmicutes. The detailed bioactivity analysis of these two Gram-positive strains revealed the different mixtures of volatile compounds with antibacterial activity. The main antibacterial compounds of the strain 1350R2-TSA30-6 are pyrrolopyrazines pyrrolo[1,2-a]pyrazine-1,4-dione, hexahydro3-(2-methylpropyl)- and pyrrolo[1,2-a]pyrazine-1,4-dione, hexahydro-3-(phenylmethyl)-. The main antibacterial compound of the strain 1410WF1-TSA30-2 is 1,2-benzenedicarboxylic acid, bis(2-methylpropyl) ester. Mixtures of the volatile antimicrobial compounds of both strains were antagonistic against Gram-positive strains isolated from Krubera-Voronja Cave, and their activity against Gram-positive pathogenic bacteria substantially differed.
\end{abstract}

Keywords: $\quad$ antimicrobial, Bacillus, cave microorganisms, Krubera-Voronja Cave, volatile compound Received 28 January 2016; Revised 15 October 2016; Accepted 15 October 2016

Citation: Klusaite A., Vickackaite V., Vaitkeviciene B., Karnickaite R., Bukelskis D., Kieraite-Aleksandrova I. and Kuisiene N., 2016. Characterization of antimicrobial activity of culturable bacteria isolated from Krubera-Voronja Cave. International Journal of Speleology, 45 (3), 275-287. Tampa, FL (USA) ISSN 0392-6672 http://dx.doi.org/10.5038/1827-806X.45.3.1978

\section{INTRODUCTION}

Antibiotic resistance of pathogenic bacteria became one of the greatest threats to human health over the last few decades (Blair et al., 2015). A few different approaches are used to resolve this problem: chemical synthesis of novel antibiotics (Wright et al., 2014), discovery and development of novel agents capable of circumventing or neutralizing the existing resistance mechanisms (Blair et al., 2015), as well as search for new natural antimicrobials (Lamprinou et al., 2015). Considering the last-mentioned approach, caves represent one of the most attractive environments with a strong potential for the discovery of novel antimicrobials. Antimicrobial activity of different cave microorganisms against pathogenic bacteria was reported previously (Herold et al., 2005; Nakaew et al., 2009; Rajput et al., 2012; Cheeptham et al., 2013; Rule \& Cheeptham, 2013; Tomova et al., 2013; Lamprinou et al., 2015); a new genus of bacteria, producing antimicrobial substances, was identified in a cave in Thailand (Nakaew et al., 2012).

Ecological conditions enabling cave microorganisms to produce antimicrobial compounds are unclear. Montano \& Henderson (2013) showed that the frequency of human visitation does not affect the antimicrobial activity of cave microorganisms, while the increasing depth, and consequently increasing oligotrophy do. Energy-starved conditions in the caves prompt the complex interactions (competitive or cooperative) between different microorganisms resulting in the production of secondary metabolites, 
such as pigments, siderophores, and antibiotics, which are used as informational cues (Rajput et al., 2012; Gabriel \& Northup, 2013). Krubera-Voronja Cave is the Earth's deepest cave (Sendra \& Reboleira, 2012). Because of its depth, high antimicrobial activity of microorganisms living in it could be expected, but it has not been investigated so far.

Antimicrobial potential of cave actinobacteria and especially Streptomyces was investigated (Herold et al., 2005; Nakaew et al., 2009; Hodges et al., 2012; Rajput et al., 2012; Cheeptham et al., 2013; Rule \& Cheeptham, 2013; Nimaichand et al., 2015), but the antimicrobial compounds of bacteria from other phyla - Cyanobacteria (Lamprinou et al., 2015), Proteobacteria and Bacteroidetes (Tomova et al., 2013) - were also of scientific interest. Our previous cultivation-independent analysis of bacterial diversity in Krubera-Voronja Cave showed that Gram-positive phyla Actinobacteria and Firmicutes were among the most numerous phyla in this cave (Kieraite-Aleksandrova et al., 2015). This indicates during the evolution the indigenous Gram-positive bacteria of Krubera-Voronja Cave could have evolved the mechanisms to compete and/or collaborate specifically with other Gram-positive bacteria. The production of antimicrobial compounds could be regarded as one of those mechanisms. Antimicrobial activity of the indigenous Gram-positive bacteria of Krubera-Voronja Cave against other Gram-positive bacteria is still unknown and should be evaluated, the rather that the search for novel antimicrobials targeting Gram-positive pathogens is of major importance. These bacteria most commonly cause severe nosocomial infections, and the resistance of these pathogens to conventionally used antimicrobials continuously increases and strengthens (Herold et al., 2005). Therefore, screening for novel narrowspectrum antimicrobials, that would be active against Gram-positive pathogens, is vital.

In the present study we aimed to perform the first analysis of antibacterial activity of microorganisms isolated from Krubera-Voronja Cave, mainly focusing on their activity against Gram-positive bacteria including Gram-positive pathogens.

\section{MATERIAL AND METHODS}

\section{Site description and sampling}

Krubera-Voronja Cave is located in the Arabica Massif (43.4184 N 40.3083 E, Western Caucasus). Sampling in Krubera-Voronja Cave was described explicitly in our previous work (Kieraite-Aleksandrova et al., 2015). It was performed on $30^{\text {th }}$ July to $7^{\text {th }}$ August 2012, at depths of $220 \mathrm{~m}$ to $1640 \mathrm{~m}$. At the time of sampling, humidity ranged from $69-76 \%$ in the upper part (220-230 $\mathrm{m}$ in depth) of the cave to $>90 \%$ in the middle (500-700 $\mathrm{m}$ in depth) and the lower (1215-1640 $\mathrm{m}$ in depth) parts of the cave. The temperature in the cave ranged from $3-4^{\circ} \mathrm{C}$ in the upper and middle parts to $6-8^{\circ} \mathrm{C}$ in the lower part of the cave.

In total, 26 samples were collected from KruberaVoronja Cave. The collected sample materials included soil and clay from cave walls, sediment, speleothems, drinkable water from the underground camps as well as coloured spots from cave walls. All samples were collected using aseptic techniques and placed into sterile microcentrifuge tubes. The samples were transported in a cooler and stored at $-20^{\circ} \mathrm{C}$ until microbial analysis was performed.

\section{Isolation of bacterial cultures}

For isolation of culturable microorganisms from water samples, $100 \mu \mathrm{L}$ of each sample was spread over different solid microbiological media dispensed in Petri dishes. For isolation of culturable microorganisms from sediment samples, $300 \mathrm{mg}$ of each sample was suspended in $700 \mu \mathrm{L}$ of saline, and $100 \mu \mathrm{L}$ of each suspension was spread over different solid microbiological media. Tryptic Soy agar (TSA) (Merck Millipore), Hickey-Tresner (HT) agar, Actinomycetes Isolation (AI) agar, Starch Casein Nitrate agar (SCNA), and Difco ${ }^{\mathrm{TM}}$ ISP medium 4 (ISP4) were used. The cultivation media were selected according to Cheeptham et al. (2013) and Hodges et al. (2012) as well as the previous data on the bacterial diversity in Krubera-Voronja Cave (KieraiteAleksandrova et al., 2015). It was previously shown that Actinobacteria, Firmicutes, and Proteobacteria were the dominant phyla in this cave. HT agar, AI agar, SCNA and ISP4 are usually used for the isolation and cultivation of Actinobacteria, and TSA is routinely used for the isolation and cultivation of Firmicutes and Proteobacteria. Two different temperatures were chosen for the isolation of microorganisms from the cave samples: $4^{\circ} \mathrm{C}$ and $30^{\circ} \mathrm{C}$. The first one was selected according to the temperature profile inside the cave $\left(3-8^{\circ} \mathrm{C}\right.$, see above); it is suitable for the growth of psychrophiles that were believed to thrive in the cave. The second temperature is suitable for the growth of psychrotolerant microorganisms that have an optimum temperature between $20^{\circ} \mathrm{C}$ and $40^{\circ} \mathrm{C}$, but could be metabolically active at the cave's temperature. Microorganisms were cultivated at $4^{\circ} \mathrm{C}$ for 7 days and at $30^{\circ} \mathrm{C}$ for 3 days. Only those microorganisms that stood apart in colony morphology and in ability to excrete soluble pigments were chosen for further work.

\section{Primary screening of microbial isolates for antibacterial activity}

In order to identify microbial isolates with antibacterial activity, a modified version of agar diffusion test (cross-streak assay) was used (Montano $\&$ Henderson, 2013). Cave microorganisms were streaked and cultivated under the same conditions and on the same solid medium which they were isolated. For example, bacterial cultures 1350R2TSA30-6 and 1410WF1-TSA30-2 were initially isolated on TSA at $30^{\circ} \mathrm{C}$. Therefore, for the primary screening for antibacterial activity, they were restreaked on TSA and cultivated at $30^{\circ} \mathrm{C}$. For screening, the plates with the streaks of the cave microorganisms were covered with a layer of sterile TSA. Test microorganisms were streaked on sterile TSA perpendicularly to the already grown streaks of the cave microorganisms. Test 
microorganisms were cultivated at $30^{\circ} \mathrm{C}$ for $24 \mathrm{~h}$. The zone of growth inhibition of the test microorganisms near the cave isolate streak indicated antimicrobial activity of the cave microorganisms. No inhibition was defined as absent interruption of the target test microorganism streak where it crossed the cave isolate streak. Gram-positive (Micrococcus luteus and Bacillus thuringiensis TL8) and Gram-negative (Escherichia coli BL21(DE3) and Pseudomonas sp. VR1) bacteria served as test microorganisms.

\section{Genotyping of the active isolates}

The bacterial genomic DNA was extracted from fresh cell culture using the GeneJETTM Genomic DNA Purification Kit (Thermo Fisher Scientific) according to the manufacturer's instructions. BOX-PCR was performed in $50 \mu \mathrm{L}$ of reaction mixture containing DreamTaq Green PCR Master Mix (2X) (Thermo Fisher Scientific), $0.5 \mu \mathrm{M}$ BOXA1R primer (5'-CTA CGG CAA GGC GAC GCT GAC G-3') and $10 \mathrm{ng}$ of bacterial genomic DNA. BOX-PCR was conducted under the following conditions: initial denaturation at $95^{\circ} \mathrm{C}$ for 2 min followed by 29 cycles, each consisting of $95^{\circ} \mathrm{C}$ for $1 \mathrm{~min}, 53^{\circ} \mathrm{C}$ for $2 \mathrm{~min}$, and $72^{\circ} \mathrm{C}$ for $3 \mathrm{~min}$ with a final extension step at $72^{\circ} \mathrm{C}$ for $7 \mathrm{~min}$. Products of amplification were analysed by electrophoresis through $1 \%$ agarose gel.

\section{Phylogenetic analysis of active isolates}

Amplification of 16S rRNA genes was done according to Kuisiene et al. (2002). PCR products were cloned into E. coli $\mathrm{DH} 5 \mathrm{a}$ using the CloneJET ${ }^{\mathrm{TM}} \mathrm{PCR}$ Cloning Kit (Thermo Fisher Scientific). Recombinant plasmids were isolated using the GeneJET ${ }^{\mathrm{TM}}$ Plasmid Miniprep Kit (Thermo Fisher Scientific). 16S rRNA genes of strains 1350R2-TSA30-6 and 1410WF1-TSA30-2 were sequenced at the DNA Sequencing Centre (Vilnius University, Institute of Biotechnology, Lithuania); the obtained sequences were edited and sequence similarity was determined using the SEQBUILDER and MEGALIGN components of LASERGENE 6 (DNASTAR). 16S rRNA gene sequences were subjected to phylogenetic analysis using ARB (Ludwig et al., 2004). The size of the $16 \mathrm{~S}$ rRNA gene used for the analysis was $1372 \mathrm{nt}$. The tree was rooted using the 16S rRNA gene sequence of Paenibacillus polymyxa DSM $36^{\mathrm{T}}$ as an outgroup.

\section{Nucleotide sequence accession numbers}

16S rRNA gene sequences of strains 1350R2TSA30-6 and 1410WF1-TSA30-2 were deposited in the GenBank under the No. KU513788 and KU513789 respectively.

\section{Evaluation of antimicrobial activity of active isolates by agar-well diffusion method}

Test microorganisms were cultivated on TSA medium at $30^{\circ} \mathrm{C}$ for $24 \mathrm{~h}$ and then resuspended in saline. The correlation between the optical density of bacterial suspensions at $600 \mathrm{~nm}$ and the number of $\mathrm{CFU} / \mathrm{mL}$ after the TSA plate counts was established for test microorganisms. For the evaluation of antimicrobial activity, the suspension of the test microorganism was mixed with molten TSA to achieve final $10^{6} \mathrm{CFU} /$ $\mathrm{mL}$. Inoculated TSA was poured into the Petri dishes (20 $\mathrm{mL}$ per dish). $5 \mathrm{~mm}$ diameter wells were cut in the inoculated agar surface and filled with $100 \mu \mathrm{L}$ of the sample. The zone of the growth inhibition of test microorganisms indicated antimicrobial activity of the sample and was recorded as a zone diameter (in millimeters) around the wells, minus 5-mm diameter of the well (Choma \& Grzelak, 2011; Tomova et al., 2013).

\section{Optimization of culture growth parameters for production of antibacterial compounds}

Effects of the concentration of nutrients, growth medium $\mathrm{pH}$, temperature and aeration on the culture growth were examined in order to optimize the production of antibacterial compounds. Effects of the concentration of nutrients were examined using 1xTryptic Soy broth (TSB), 0.5xTSB and highly nutritious growth medium Brain Heart Infusion broth (BHIB). To test the effect of $\mathrm{pH}$, growth medium was prepared in $50 \mathrm{mM}$ Tris-HCl buffer $(\mathrm{pH} 7,8$, and $9 / 20^{\circ} \mathrm{C}$ ). For determination of the effect of temperature, $30^{\circ} \mathrm{C}$ (the isolation temperature), $16^{\circ} \mathrm{C}, 8^{\circ} \mathrm{C}$ (the upper temperature limit of the cave), and $4^{\circ} \mathrm{C}$ (the lower temperature limit of the cave) were chosen. The effect of aeration was determined at $180 \mathrm{rpm}$ and $250 \mathrm{rpm}$ in an orbital shaker Multitron Standard (INFORS HT).

Inoculation $(5 \%$ vol/vol) was performed using bacterial cultures grown for $12 \mathrm{~h}$ on TSA plates at $30^{\circ} \mathrm{C}$. Inocula were prepared in the respective sterile growth medium. Bacteria were cultivated in $250 \mathrm{~mL}$ Erlenmeyer flasks, and the samples were aseptically removed every $2 \mathrm{~h}$ to determine culture growth and production of antimicrobial compounds. Growth of the culture was monitored by measuring optical density at $600 \mathrm{~nm}$, and antimicrobial activity of the culture was assayed in the culture supernatant by agar-well diffusion method (see above). Cells from the liquid culture were removed by centrifugation $(7000 \times \mathrm{g}, 20$ $\left.\min , 4^{\circ} \mathrm{C}\right)$.

\section{Extraction of antibacterial compounds by salting- out with ammonium sulphate}

Active bacterial strains were cultivated in buffered $0.5 x T S B$ for $12 \mathrm{~h}$ at $30^{\circ} \mathrm{C}$ at $180 \mathrm{rpm}$ in the orbital shaker Multitron Standard (INFORS HT). Cells were removed by centrifugation $(7000 \times \mathrm{g}, 20 \mathrm{~min}$, $4^{\circ} \mathrm{C}$ ), and solid ammonium sulphate was added to the supernatant to achieve $80 \%$ saturation. The precipitate was recovered by centrifugation $(12000 \times \mathrm{g}$, $\left.20 \mathrm{~min}, 4^{\circ} \mathrm{C}\right)$, then dissolved in $20 \mathrm{mM}$ Tris- $\mathrm{HCl}$ buffer ( $\mathrm{pH} 7$ ). The dissolved proteins were evaluated for the antimicrobial activity using agar-well diffusion method. The dissolved proteins were also treated with recombinant proteinase $\mathrm{K}$ (Thermo Fisher Scientific) according to the manufacturer's instructions. Antimicrobial activity of hydrolysed proteins was also evaluated using agar-well diffusion method. Protein concentration was determined using the Pierce ${ }^{\mathrm{TM}}$ Coomassie (Bradford) Protein Assay Kit (Thermo Fisher Scientific) according to the manufacturer's instructions. 


\section{Extraction of antibacterial compounds by organic solvents}

Active strains were cultivated in $100 \mathrm{~mL}$ of buffered $0.5 x \mathrm{TSB}$ for $12 \mathrm{~h}$ at $30^{\circ} \mathrm{C}$ at $180 \mathrm{rpm}$ in the orbital shaker Multitron Standard (INFORS HT). Cells were removed by centrifugation $\left(7000 \times \mathrm{g}, 20 \mathrm{~min}, 4^{\circ} \mathrm{C}\right)$. Antibacterial compounds in the supernatant were extracted with equal volume of acetone, chloroform, ethyl acetate, methanol, and hexane in a separating funnel. Different supernatant samples of the same culture were separately extracted with each solvent. The organic solvent extracts were evaporated to dryness and dissolved in chloroform (Sanghvi et al., 2014).

\section{Thin layer chromatography and bioautography}

Thin layer chromatography (TLC) of chloroform extract was done on Silica gel $60 \mathrm{~F}_{254}$ plates (Merck Millipore). The antibacterial compounds were separated with ethyl acetate-methanol (3:1, vol/vol) solvent system. Chromatograms were observed under UV light and exposed to iodine vapours. Bioautography was used for the localization of antibacterial compounds in chloroform extract (Attimarad et al., 2012). TLC plate with the separated antibacterial compounds was dried, put in sterile Petri dish, and overlaid with the inoculated TSA. Inoculated TSA was prepared as described above for the agar well diffusion method. $M$. luteus was used for bioautography as the test microorganism. After incubation at $30^{\circ} \mathrm{C}$ for $24 \mathrm{~h}$, the zone of inhibition around the spot of antibacterial compound was determined. The fractions with antibacterial activity were recovered from TLC plates, disssolved in ethyl acetate and subjected to further analysis.

\section{Gas chromatography-mass spectrometry (GC-MS) analysis of antibacterial compounds}

Gas chromatographic (GC) analysis of the fractions with antibacterial activity recovered from TLC plates was performed on a PerkinElmer Clarus 580 series gas chromatograph coupled to a PerkinElmer Clarus 560 $\mathrm{S}$ mass spectrometer (PerkinElmer, Shelton, USA). The GC system was equipped with Elite-5MS capillary column (30 $\mathrm{m} \times 0.25 \mathrm{~mm}$ id, $0.25 \mu \mathrm{m}$ film thickness) coated with methylpolysiloxane (5\% phenyl). Helium was employed as a carrier gas with a constant flow of $1 \mathrm{~mL} / \mathrm{min}$. GC conditions were as follows: the oven temperature was programmed: $40^{\circ} \mathrm{C}$ for $1 \mathrm{~min}$, from 40 to $250^{\circ} \mathrm{C}$ at $3^{\circ} \mathrm{C} / \mathrm{min}$ and held at $250^{\circ} \mathrm{C}$ for $8 \mathrm{~min}$; the injector temperature was held at $250^{\circ} \mathrm{C}$. Injection was performed in pulsed splitless mode (pulsed to 4 $\mathrm{mL} / \mathrm{min}$ until $1.5 \mathrm{~min}$, split (10:1) open at $1.55 \mathrm{~min})$. The capillary column was connected to the ion source of the mass spectrometer by means of the transfer line maintained at $280^{\circ} \mathrm{C}$. The electron ionization ion source conditions were: electron energy $70 \mathrm{eV}$ and temperature $180^{\circ} \mathrm{C}$. GC-MS in full scan mode was used. The analyses were carried out with a filament multiplier delay of $3 \mathrm{~min}$, and the acquisition was performed in the range of $\mathrm{m} / \mathrm{z} 33$ - 600. The qualitative identification of different compounds was performed by comparing their mass spectra with those stored in the NIST (The National Institute of Standards and Technology) library. The relative amounts of individual compounds were expressed as percentages of the peak area relative to the total peak area. GC-MS identified compounds were compared with the bacterial organic volatile compounds included in the Microbial Volatile Organic Compounds (mVOC) database (Lemfack et al., 2014) as well as with those in the SuperScent database (Dunkel et al., 2009).

\section{Evaluation of antibacterial activity against pathogens and microorganisms of the cave}

For evaluation of antibacterial activity against pathogens and microorganisms of the cave, the active fractions, recovered from TLC plates and dissolved in ethyl acetate, were used.

Antibacterial activity was determined against Gram-positive pathogenic bacteria: Bacillus cereus ATCC 10876 (Firmicutes), Enterococcus faecalis ATCC 29212 (Firmicutes), Listeria monocytogenes ATCC 7644 (Firmicutes), Staphylococcus aureus subsp. aureus ATCC 25923 (Firmicutes), and Rhodococcus equi ATCC 6939 (Actinobacteria). Agar-well diffusion method was used for determination of the minimal inhibitory concentration (MIC). The inocula of the pathogenic bacteria were prepared in saline and matched 0.5 McFarland standard. $19 \mathrm{~mL}$ of melted and cooled down TSA medium was inoculated with $1 \mathrm{~mL}$ of such suspension and poured into Petri dish. The final concentration of cells in TSA was $10^{6} \mathrm{CFU} /$ $\mathrm{mL} .5 \mathrm{~mm}$ diameter wells were cut in the inoculated agar surface and filled with $100 \mu \mathrm{L}$ of the sample. Six different concentrations of antimicrobial compounds were used for determination of MIC: $4.66 \mathrm{mg} / \mathrm{mL}$ (the undiluted sample), $2.33 \mathrm{mg} / \mathrm{mL}$ (1:1 dilution), 1.165 $\mathrm{mg} / \mathrm{mL}$ (1:3 dilution), $582.5 \mu \mathrm{g} / \mathrm{mL}$ (1:7 dilution), $291.25 \mathrm{\mu g} / \mathrm{mL}$ (1:15 dilution), and $145.625 \mu \mathrm{g} / \mathrm{mL}$ (1:31 dilution).

In the current work antibacterial activity of the active fractions was also examined against bacteria isolated from Krubera-Voronja Cave: Gram-positive strain 28TSA30-8, Brevibacillus sp. 1410WF1-HT30-5, Paenibacillus sp. 23TSA30-6, Paenibacillus sp. 28ISP30-5, and Streptomyces sp. 1350R2-SCNA30. Modified agar-well diffusion method was used for this test. Sterile TSA $(20 \mathrm{~mL})$ was poured into the Petri dish, and the well was cut in agar in the centre of the Petri dish. Bacterial cultures were streaked from the edge of the well to the border of the Petri dish. Then the well was filled with $100 \mu \mathrm{L}$ of the sample containing antimicrobial compounds at a concentration of 1.165 $\mathrm{mg} / \mathrm{mL}$. Growth inhibition indicated the antibacterial activity of the tested compounds.

\section{RESULTS}

\section{Isolation and antibacterial activity of microorganisms from samples of Krubera-Voronja Cave}

In total, 874 heterotrophic cultures were isolated using five different media: TSA, HT agar, AI agar, SCNA, and ISP4. 108 isolates were from water samples, and 766 - from sediment samples collected in Krubera-Voronja Cave at the depth from $220 \mathrm{~m}$ 
to $1640 \mathrm{~m}$ (Kieraite-Aleksandrova et al., 2015). The largest number of cultures was isolated on TSA $(93$ isolates at $4^{\circ} \mathrm{C}$ and $141-$ at $\left.30^{\circ} \mathrm{C}\right)$ and $\mathrm{HT}$ agar $(207$ isolates at $30^{\circ} \mathrm{C}$ ). The smallest number of isolates was obtained using AI agar -138 at $30^{\circ} \mathrm{C}$. In general, temperature of $30^{\circ} \mathrm{C}$ was more suitable for the growth of heterotrophs -714 cultures were obtained at this temperature, while only 160 cultures - at $4^{\circ} \mathrm{C}$. Only TSA and ISP4 were suitable for growth at the latter temperature.

In order to examine antibacterial activity of the isolated cultures, primary screening using agar diffusion test was performed. Out of 874 cultures, 122 isolates $(14.0 \%)$ demonstrated antibacterial activity. 108 active isolates were obtained from sediment samples, and 14 - from water samples. Most (63.9\%) of the active isolates inhibited growth of a single test microorganism, while four isolates possessed a broad activity spectrum, being antagonistic against all test microorganisms. Only $9.3 \%$ of isolates from the upper part of the cave (sampling at 220-230 $\mathrm{m}$ in depth) showed antimicrobial activity, while $11.1 \%$ and $14.1 \%$ of all isolates from the middle (sampling at 500-700 $\mathrm{m}$ in depth) and lower (sampling at 1215-1640 $\mathrm{m}$ in depth) parts of Krubera-Voronja Cave, respectively, inhibited growth of at least one test strain.

Our previous cultivation-independent analysis showed that Gram-positive phyla Actinobacteria and Firmicutes were among the dominant phyla in KruberaVoronja Cave (Kieraite-Aleksandrova et al., 2015). Therefore, we particularly focused on the isolates that exhibited antagonism only against Gram-positive but not against Gram-negative test microorganisms. In total, 31 isolates inhibited growth of two different test strains, and 24 of them were active only against Gram-positive ones. Activity of most of these 24 isolates against both Gram-positive test strains was very weak; somewhat stronger activity was observed only for seven cave isolates. Two cave isolates, 1350R2-TSA30-6 and 1410WF1-TSA30-2, were chosen for further experiments because of their high and comparable activity against both Gram-positive test strains - M. luteus from phylum Actinobacteria and $B$. thuringiensis TL8 from phylum Firmicutes. Both 1350R2-TSA30-6 and 1410WF1-TSA30-2 were isolated on TSA at $30^{\circ} \mathrm{C}$ from samples 1350R2 and 1410WF1 that have been collected in the lower part (1350 $\mathrm{m}$ and $1410 \mathrm{~m}$ depth) of Krubera-Voronja Cave. Sample 1350R2 was the sample of white clay from the rarely visited branch of the cave, and sample 1410WF1 was the sample of water from the underground camp (Kieraite-Aleksandrova et al., 2015).

\section{Genotyping and phylogenetic analysis of active isolates}

In order to determine whether isolates 1350R2TSA30-6 and 1410WF1-TSA30-2 represent two different strains, BOX-PCR genotyping was performed. Our analysis clearly showed that these two isolates belong to two different strains (Fig. 1).

16S rRNA genes of these two strains were cloned, sequenced and analysed. The BLAST search showed that both strains belong to the family Bacillaceae in phylum Firmicutes. Both strains were assigned to the genus Bacillus (Fig. 2). 16S rRNA gene of the strain 1410WF1-TSA30-2 was most similar to those of Bacillus aerophilus, Bacillus altitudinis and Bacillus stratosphericus with $99.9 \%$ sequence similarity. Strain 1350R2-TSA30-6 clustered with Bacillus simplex, Bacillus frigoritolerans and Bacillus muralis with $99.8 \%, 99.6 \%$ and $99.5 \%$ sequence similarity respectively.

\section{The effect of culture growth parameters for the production of antibacterial compounds}

Optimization experiments showed that growth of a culture as well as production of antibacterial compounds depended on the concentration of nutrients in a culture medium. For the strain 1350R2TSA30-6, the highest optical density (OD600) as well as the largest antimicrobial activity were observed in $0.5 x$ TSB (data for BHIB not shown) (Fig. 3). For the strain 1410WF1-TSA30-2, similar maximum OD600 and antibacterial activity were obtained in TSB and $0.5 \mathrm{xTSB}$, but the growth rate was higher in $0.5 \mathrm{xTSB}$ (Fig. 3). BHIB was the worst choice for the strain 1410WF1-TSA30-2 in terms of both culture growth and antibacterial activity (data not shown). Therefore, for both strains further optimization experiments were carried out in $0.5 \times \mathrm{TSB}$.

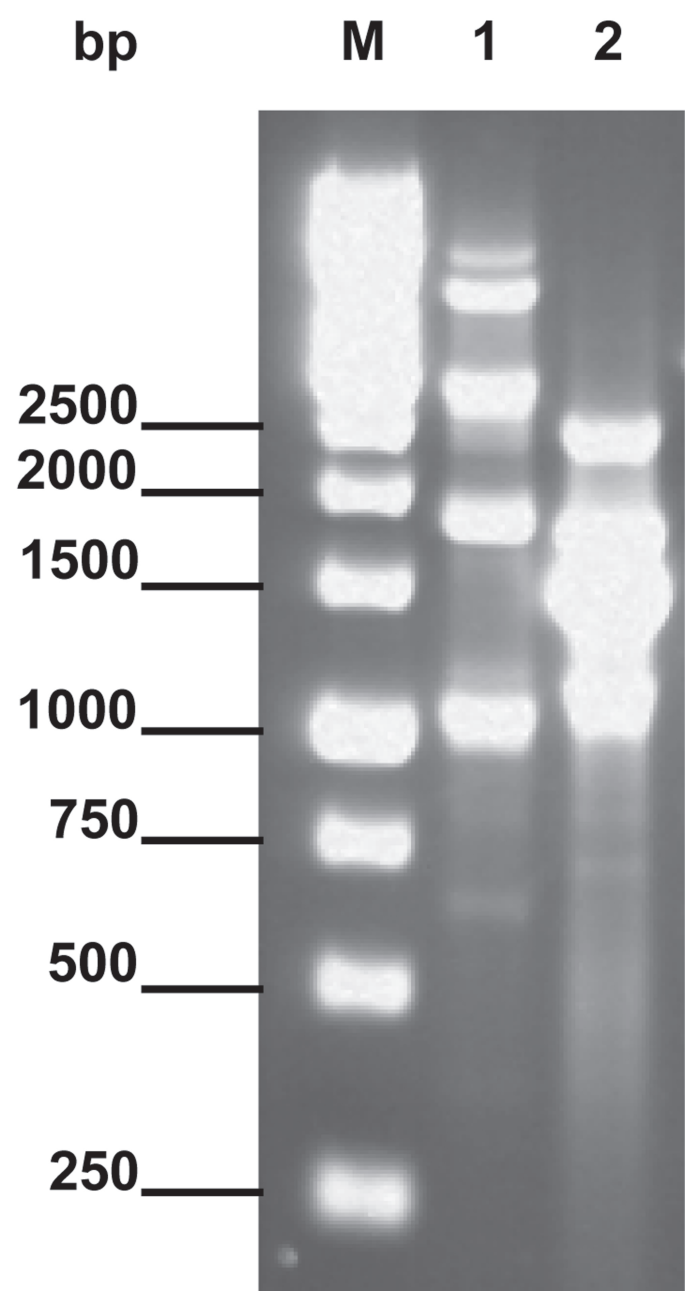

Fig. 1. BOX-PCR electrophoretic profiles. M - GeneRuler $1 \mathrm{~kb}$ DNA Ladder (Thermo Fisher Scientific); 1 - 1350R2TSA30-6; 2 - 1410WF1-TSA30-2. The results of this test indicate that isolates 1350R2-TSA30-6 and 1410WF1TSA30-2 are distinct. 


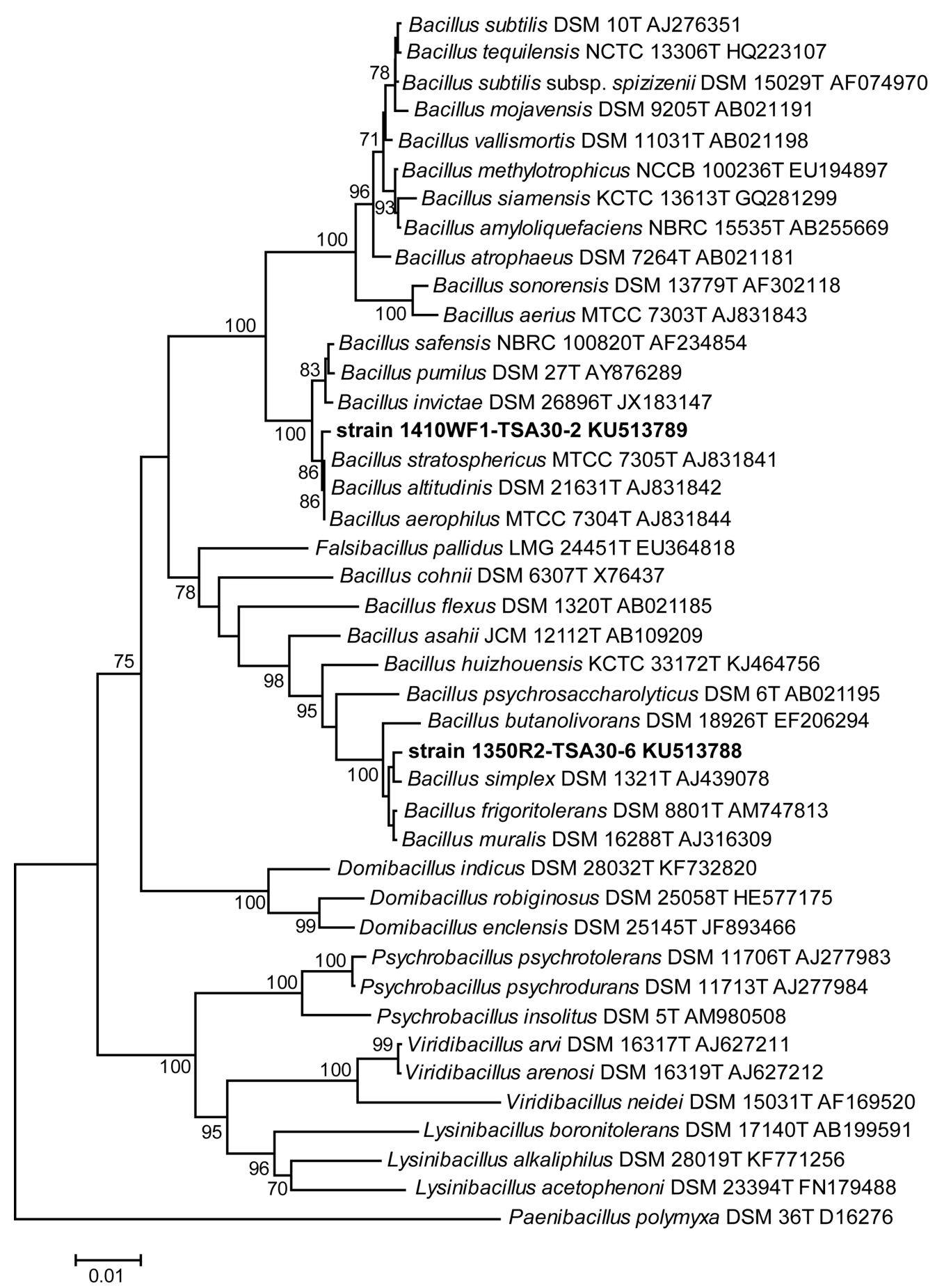

Fig. 2. Phylogenetic positions of strains 1350R2-TSA30-6 and 1410WF1-TSA30-2 as well as the nearest neighbors from the family Bacillaceae. The numbers at the nodes represent percent of bootstrap values obtained from 1000 samplings. Only the most significant values (higher than 70\%) are presented. Paenibacillus polymyxa DSM 36T was defined as an outgroup of the tree. Scale bar, 0.01 nucleotide substitution per site.

Both the growth of a culture and the production of antibacterial compounds were influenced by $\mathrm{pH}$ of a culture medium. The best $\mathrm{pH}$ for the strain 1350R2TSA30-6 was pH 7, and for the strain 1410WF1-TSA30-2 it was $\mathrm{pH} 9$. Aeration did not influence the results of our experiments; highly similar results were obtained for both $180 \mathrm{rpm}$ and $250 \mathrm{rpm}$. Low $\left(16^{\circ} \mathrm{C}\right)$ temperature was not suitable for the growth of both strains - the strain 1410WF1-TSA30-2 did not grow, and OD600 for the strain 1350R2-TSA30-6 at this temperature was $\sim 3.3$ times lower than at $30^{\circ} \mathrm{C}$. Consequently, the growth in the liquid culture at $8^{\circ} \mathrm{C}$ and $4^{\circ} \mathrm{C}$ was not tested.

Based on these results, both strains were further cultivated in buffered $0.5 \times \mathrm{TSB}$ at $30^{\circ} \mathrm{C}$ at $180 \mathrm{rpm}$.
$\mathrm{pH}$ of the medium was adjusted to 7 for cultivation of the strain 1350R2-TSA30-6 and to 9 for cultivation of the strain 1410WF1-TSA30-2. Growth curves and antimicrobial activity, obtained after the optimization experiments, are shown in Fig. 3. It is noteworthy that for both strains the production of antimicrobial compounds started in the exponential growth phase and continued during the growth of the culture.

\section{Extraction of antimicrobial compounds}

Two different approaches were used for the extraction of antimicrobial compounds from the culture supernatant - salting-out with ammonium sulphate and extraction by organic solvents. 


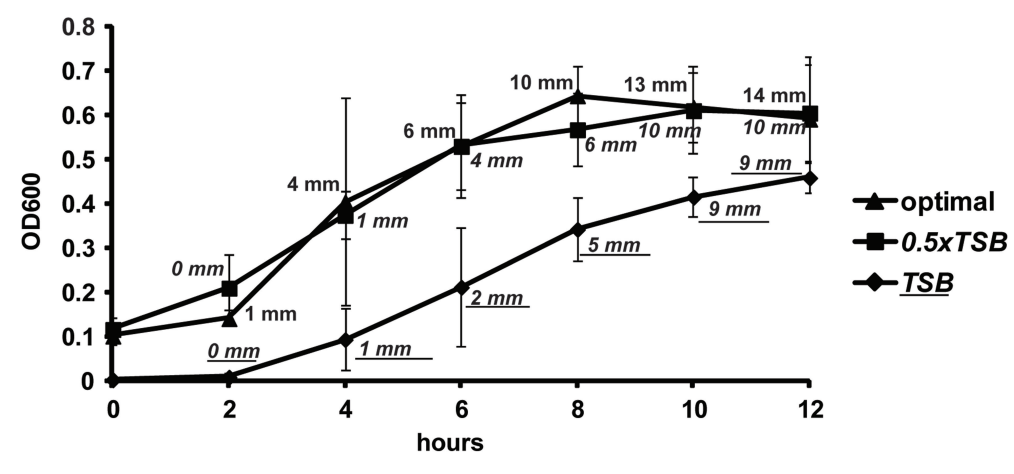

1350R2-TSA30-6

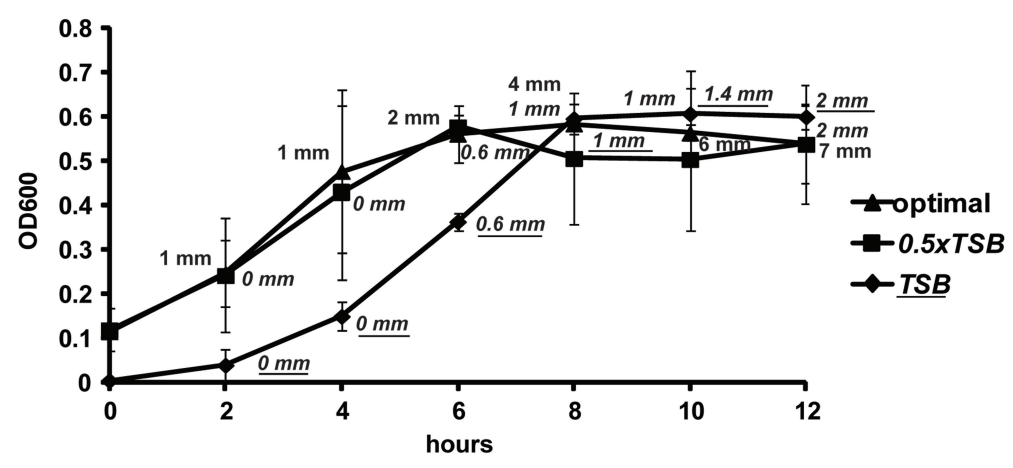

1410WF1-TSA30-2

Fig. 3. Optimization of the nutrient concentrations. Effect on the culture growth and production of antibacterial compounds is shown. The width of inhibition zones is expressed in millimeters and shown at the sampling points. "Optimal" is the growth curve and antimicrobial activity under optimal conditions: $0.5 \times \mathrm{TSB}$ in $50 \mathrm{mM}$ Tris$\mathrm{HCl}, \mathrm{pH} 7,30^{\circ} \mathrm{C}, 180 \mathrm{rpm}$ for strain $1350 \mathrm{R} 2-\mathrm{TSA} 30-6$ and $0.5 \times \mathrm{TSB}$ in $50 \mathrm{mM}$ Tris$\mathrm{HCl}, \mathrm{pH} 9,30^{\circ} \mathrm{C}, 180 \mathrm{rpm}$ for strain $1410 \mathrm{WF} 1-\mathrm{TSA} 30-2$. "0.5xTSB" is the growth curve and antimicrobial activity under the following conditions: $0.5 \times \mathrm{TSB}, \mathrm{pH} 7$ (unbuffered medium), $30^{\circ} \mathrm{C}, 250 \mathrm{rpm}$ for both strains. "TSB" is the growth curve and antimicrobial activity under the following conditions: $1 \times 1$ TSB, $\mathrm{pH} 7$ (unbuffered medium), $30^{\circ} \mathrm{C}, 250 \mathrm{rpm}$ for both strains.

Salted-out extracellular proteins of strains 1350R2TSA30-6 and 1410WF 1-TSA30-2 showed antibacterial activity against $M$. luteus (data not shown). The treatment with proteinase $\mathrm{K}$ did not diminish this activity. These experiments allowed us to suggest that antimicrobial compounds produced by both strains are not peptides or proteins.

Acetone, chloroform, ethyl acetate, methanol, and hexane were used separately for extraction of the different aqueous samples of the same culture by organic solvents. All extractions were successful; antibacterial activity was detected in all extracts for both strains. Antimicrobial activity of the extracts of the strain 1350R2-TSA30-6 was considerably higher than of the extracts of the strain 1410WF1-TSA30-2. It was detected that different extracts of the strain 1410WF1-TSA30-2 exhibited comparable activity for all solvents used, while hexane and chloroform extracts were the most active in the case of strain 1350R2-TSA30-6 (Table 1). So, chloroform extracts were used for characterization of antimicrobial compounds produced by both strains.

\section{Characterization of antimicrobial compounds}

Antimicrobial compounds of strains 1350R2-TSA30-6 and 1410WF1-TSA30-2 were analysed using TLC and bioautography. Both strains showed two different fractions on TLC plates, but only a single fraction of each strain showed antimicrobial activity against Gram-positive bacteria $M$. luteus (Fig. 4). Retardation factor $\left(R_{\mathrm{f}}\right)$ of the compounds with antimicrobial activity differed. $R_{\mathrm{f}}$ for the compound of the strain 1350R2-TSA30-6 was 0.85 , and for the strain 1410WF1-TSA30-2 it was 0.93 . The active compounds were recovered from the TLC plates and analysed by GC-MS.

GC-MS was used to determine a chemical composition of the two active TLC fractions. Main components of the active fraction of the strain 1350R2-TSA30-6 were pyrrolizidines (Table 2, compounds No. 8-12). Their total amount was $60.3 \%$. For four peaks (RT 46.23, 49.58, 50.19, and $58.70 \mathrm{~min}$, compounds No. 8-11 in Table 2), the highest match with the library data was for pyrrolo[1,2-a]pyrazine-1,4-dione, hexahydro-3(2-methylpropyl)-. Clearly, those peaks should represent four different compounds. We could suppose that pyrrolo[1,2-a]pyrazine-1,4-dione, hexahydro-3-(2-methylpropyl)- corresponds to the compound with RT 50.19 min (Table 2, compound No. 10), as its mass spectrum shows the highest match with the library data. Other three peaks should correspond to the compounds with very similar structure, as their mass spectra are quite similar with a very intense fragment peak at $\mathrm{m} / \mathrm{z} 154$ that could be attributed to hexahydro pyrrolo[1,2-a]pyrazine-1,4-dione (molecular mass 154). When harsh electron ionization is applied, the compounds undergo fragmentation and their molecular ions are not intense. Two of the compounds (with RT 49.58 and $50.19 \mathrm{~min}$ - Table 2, compounds No. 9 and 10 respectively) have the same molecular ion with $\mathrm{m} / \mathrm{z} 210$ indicating that they could be isomers of pyrrolo[1,2-a]pyrazine-1,4-dione, hexahydro-3(2-methylpropyl)-. A compound eluting at 46.23 min (Table 2, compound No. 8) has a molecular ion of $\mathrm{m} / \mathrm{z} 196$ and probably could be identified as pyrrolo[1,2-a]pyrazine-1,4-dione, hexahydro-3(2-isopropyl)-. A compound eluting at $58.70 \mathrm{~min}$ (Table 2, compound No. 11) has a low intensity molecular ion peak at $\mathrm{m} / \mathrm{z}$ 343. Unfortunately, very few mass spectra of related compounds can be found in the library, thus more precise identification was not possible. It should be noted that pyrrolopyrazines pyrrolo[1,2-a]pyrazine-1,4-dione, hexahydro-3-(2-methylpropyl)- and pyrrolo[1,2-a] pyrazine-1,4-dione, hexahydro-3-(phenylmethyl)are semivolatile cyclic dipeptides also called cyclo

Table 1. Antimicrobial activity of organic solvents' extracts. Micrococcus luteus was used as the test microorganism in this agar-well diffusion assay, the width of the inhibition zone is shown in millimeters.

\begin{tabular}{|l|c|c|c|c|c|}
\hline \multicolumn{1}{|c|}{ Strain } & Ethyl acetate & Acetone & Hexane & Chloroform & Methanol \\
\hline 1350R2-TSA30-6 & 1.5 & 3.0 & 4.0 & 3.5 & 2.0 \\
\hline 1410WF1-TSA30-2 & 1.0 & 1.5 & 1.5 & 1.0 & 1.5 \\
\hline
\end{tabular}



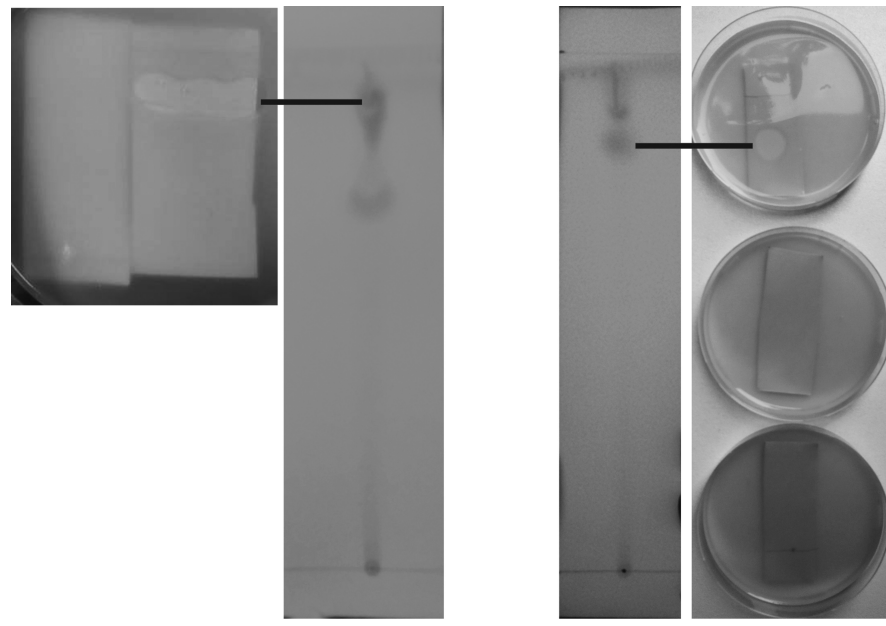

1410WF1-TSA30-2

1350R2-TSA30-6

Fig. 4. Thin layer chromatography and bioautography of chloroform extracts. Micrococcus luteus was used for bioautography as the test microorganism. Both 1350R2-TSA30-6 and 1410WF1-TSA30-2 showed two different fractions on TLC plates, but only a single fraction of each strain showed antimicrobial activity.

(L-leucyl-L-prolyl) (or 2,5-diketopiperazine antibiotic gancidin W) and cyclo(L-prolyl-D-phenylalanyl) respectively.

Nineteen main compounds with the content of $\geq 0.5 \%$ were identified in active fraction of the strain 1410WF1-TSA30-2 (Table 3). The set of volatile compounds differed for both strains, the only common compound was 1,2-benzenedicarboxylic acid, diisooctyl ester (Table 2, compound No. 13; Table 3, compound No. 19). It should be noted, that only some of the identified constituents of active fractions were volatiles previously identified in other bacteria (Tables 2, 3).

\section{Spectrum of inhibitory activity of antimicrobial compounds}

The active TLC fractions of strains 1350R2TSA30-6 and 1410WF1-TSA30-2 were evaluated for their antimicrobial activity against Gram-positive pathogenic bacteria as well as against bacteria isolated from Krubera-Voronja Cave.

The highest activity of active TLC fraction of the strain 1350R2-TSA30-6 was observed against $R$. equi ATCC 6939, while the lowest activity was recorded against S. aureus subsp. aureus ATCC 25923 and $B$. cereus ATCC 10876 (Table 4). The concentration $0.291 \mathrm{mg} / \mathrm{mL}$ was still inhibitory for all tested pathogenic strains, except for $S$. aureus subsp. aureus ATCC 25923. The MIC for the strain of $S$. aureus subsp. aureus was $0.583 \mathrm{mg} / \mathrm{mL}$, while for other four pathogenic strains it was $0.291 \mathrm{mg} / \mathrm{mL}$ (Table 4). It should be noted, that the active TLC fraction was the only partially purified mixture of compounds, therefore, the inhibitory concentrations could not be evaluated for the discrete active compounds.

Antibacterial compounds of the strain 1350R2TSA30-6 also inhibited growth of other bacteria of Krubera-Voronja Cave: Streptomyces sp. 1350R2SCNA30, Brevibacillus sp. 1410WF1-HT30-5, and Paenibacillus sp. 23TSA30-6 (Fig. 5).

The active fraction of strain 1410WF1-TSA30-2 showed no antimicrobial activity against the tested pathogenic bacteria. But antimicrobial compounds of this strain had inhibitory effect on the growth of other bacteria isolated from Krubera-Voronja Cave (Fig. 5). Only Streptomyces sp. 1350R2-SCNA30 was resistant to antibacterial compounds produced by the strain 1410WF1-TSA30-2.

\section{DISCUSSION}

For isolation of microorganisms from KruberaVoronja Cave, general purpose media (TSA) as well as the growth media designed for the isolation and cultivation of actinobacteria (HT agar, AI agar, SCNA, ISP4) were used. The choice of the latter four media was based on the well-known antimicrobial activity of the members of phylum Actinobacteria (Rule \& Cheeptham, 2013). Nevertheless, the percentage (14.0\%) of Krubera-Voronja Cave isolates, that produce antimicrobial compounds, was quite low and comparable to some shallow caves: Backcountry Cave (6 $\mathrm{m}$ in depth), Spider Cave (44 $\mathrm{m}$ in depth), and Fort Stanton Cave (134 $\mathrm{m}$ in depth) $-21.1 \%, 19.8 \%$ and 8.6\% respectively (Montano \& Henderson, 2013). On the other hand, data for some other shallow caves show higher percentage of active isolates than of Krubera-Voronja Cave: 66\% for the Left Hand Tunnel passage in Carlsbad Cavern (316 $\mathrm{m}$ in depth), 40\% for Lechuguilla Cave (489 $\mathrm{m}$ in depth) (Montano \& Henderson, 2013), 57\% for Helmckens Falls Cave (Rule \& Cheeptham, 2013), 73.9\% for Magura Cave (56 $\mathrm{m}$ in depth) (Tomova et al., 2013). Our results also showed that the percentage of bacteria capable of antagonistic activity increased from the upper to the lower part of the cave. These results were in accordance with the findings of Montano \& Henderson (2013) who revealed that the increasing depth influenced the antimicrobial activity of the cave isolates. To the best of our knowledge, our present study is the first report on the antimicrobial activity of bacterial isolates in Krubera-Voronja Cave.

Table 4. Antibacterial activity of the active TLC fraction of strain 1350R2-TSA30-6 against pathogenic bacteria. The width of the inhibition zone is shown in millimeters.

\begin{tabular}{|l|c|c|c|c|c|}
\hline \multirow{2}{*}{ Pathogen } & \multicolumn{4}{c|}{ The concentration of the antimicrobial compounds } \\
in ethyl acetate, mg/mL \\
\cline { 2 - 6 }
\end{tabular}



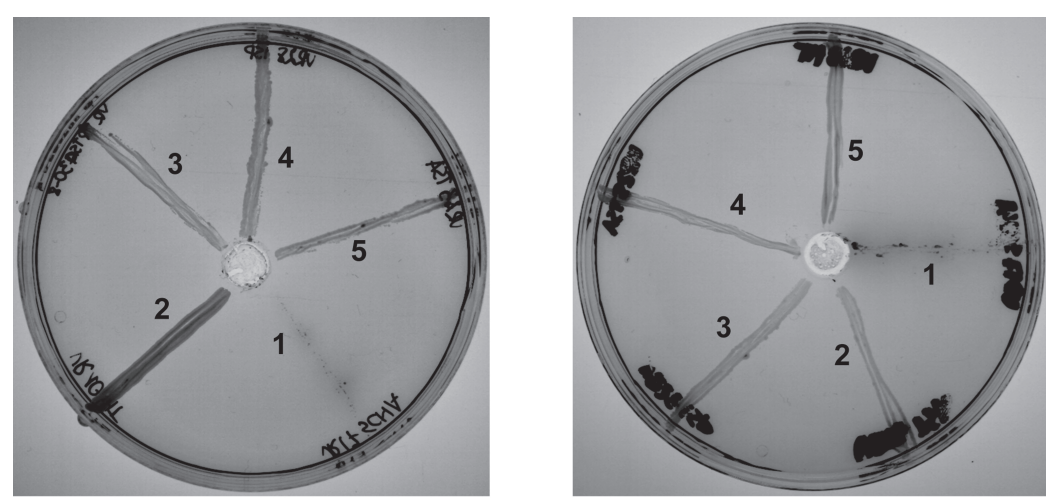

1350R2-TSA30-6

1410WF1-TSA30-2

Fig. 5. Antibacterial activity of active TLC fractions against bacteria isolated from KruberaVoronja Cave. The concentration of antimicrobial compounds in ethyl acetate was 1.165 $\mathrm{mg} / \mathrm{mL}$. 1 - Streptomyces sp. 1350R2-SCNA30; 2 - Brevibacillus sp. 1410WF1-HT30-5; 3 - Gram-positive strain 28TSA30-8; 4 - Paenibacillus sp. 28ISP30-5; 5 - Paenibacillus sp. 23TSA30-6.

The other focus of our research was the antibacterial activity targeting Gram-positive bacteria. It should be noted that Gram-positive pathogens are a major cause of nosocomial bacterial infections. Staphylococci, enterococci, streptococci, and Clostridium difficile are the most important species of clinical interest (Rossolini et al., 2014). Antibiotic resistance issues are common among Gram-positive pathogens, and the percentage of nosocomial infections caused by antibiotic-resistant Gram-positive bacteria is increasing. For example, in the United States, approximately $60 \%$ of staphylococcal infections are now caused by multidrug-resistant $S$. aureus, and these percentages continue to rise (Rice, 2006). Therefore, the development of novel antibiotics that would be active against Gram-positive pathogens is imperative. Only a small portion (24 out of 874) of bioactive isolates were antagonistic exclusively against Gram-positive bacteria, moreover - the bioactivity of the most of these 24 isolates was very weak. Two most active strains 1350R2-TSA30-6 and 1410WF1-TSA30-2, isolated from the lower part of the cave, were chosen for detailed characterization of the antimicrobials. It is of interest that these strains, although antagonistic against Gram-positive test strains $M$. luteus and $B$. thuringiensis TL8, were also Gram-positive - both strains were assigned to the genus Bacillus.

Bacteria of the family Bacillaceae are mainly known for their antimicrobial peptides - both ribosomally and nonribosomally synthesized peptide antibiotics. Nonribosomally synthesized antibiotic bacitracin A is produced by Bacillus licheniformis, lipopeptides surfactin, iturin, bacillomycin, and fengycin are produced by several strains of Bacillus subtilis. Well-known ribosomally synthesized peptides (bacteriocins) of Bacillaceae include subtilin and subtilosin A from B. subtilis; coagulin from Bacillus coagulans; bacthuricin $\mathrm{F} 4$, thuricin 17 , entomocin 9 , and tochicin from $B$. thuringiensis; cerecin 7 from $B$. cereus; bacillocin 490 from $B$. licheniformis (Sumi et al., 2015). On the other hand, bacilli also produce non-peptide antimicrobial compounds, such as bis (2-ethylhexyl) phthalate, synthesized by Bacillus pumilus (Moushumi Priya \& Jayachandran,
2012); macrolide antibiotics macrolactins 1-3 produced by Bacillus sp. (Mondol et al., 2011); macrolides gageomacrolactins 1-3 produced by $B$. subtilis (Tareq et al., 2013). Therefore, production of both antimicrobial peptides and non-peptide antibiotics was expected for bioactive strains from Krubera-Voronja Cave.

The antimicrobials of strains 1350R2TSA30-6 and 1410WF1-TSA30-2 differed significantly. The active compounds behaved differently in some organic solvents during extraction as well as had different $R_{\mathrm{f}}$ values in TLC. It was also noticed that antimicrobial substances of the strain 1350R2-TSA30-6 were stable, and the inhibition zone was visible constantly during the growth of the test microorganism in bioautography experiments, while antimicrobial substances of the strain 1410WF1-TSA30-2 inhibited the test microorganism only at the first stages of its growth, but disappeared through further cultivation due to evaporation of active compounds or their inactivation by the growing culture of $M$. luteus (data not shown). Activity of antimicrobials of the strain 1350R2TSA30-6 was higher than of strain 1410WF1-TSA30-2. The common characteristics for both strains included poor production of antimicrobials in a highly rich growth medium BHIB as well as continued production of active compounds during the growth of the culture starting in the exponential growth phase. The first characteristic can be associated with the need to produce antimicrobials under starvation, but not under the nutrient-rich growth conditions (Montano $\&$ Henderson, 2013). The second feature (the time of production) indicated that antimicrobial compounds (or at least some of them) were primary metabolites (Sanchez \& Demain, 2008).

Chemical compounds in the active TLC fractions of both strains differed markedly. The main antibacterial agents of the strain 1350R2-TSA30-6 were 2,5-diketopiperazine antibiotics. Most of 2,5-diketopiperazines are stable to proteolysis (PérezPicaso et al., 2009), and we have also observed this effect after treatment of the salted-out extracellular proteins of the strain 1350R2-TSA30-6 with proteinase $\mathrm{K}$. Antitumor, antifungal, antiviral, and antibacterial activities of cyclic dipeptides are well-known (Yan et al., 2004; Pandey et al., 2010; de Carvalho \& Abraham, 2012; Kumar et al., 2014). Cyclic dipeptides are usually produced by Gram-negative bacteria, but have been also isolated from Gram-positive. Among the genera of the family Bacillaceae, they were so far identified only in the genus Bacillus (de Carvalho \& Abraham, 2012; Leyton et al., 2012). Because of their activity spectrum, cyclic dipeptides attract much attention as potential pharmaceuticals. Our results clearly showed that antibacterial fraction of the strain 1350R2-TSA30-6 was active against Grampositive pathogenic bacteria $B$. cereus, E. faecalis, $L$. monocytogenes, $S$. aureus subsp. aureus, and $R$. equi. Cyclic dipeptides are secondary metabolites (Leyton et al., 2012), therefore, if they would be the only compounds with bioactivity, then the antimicrobial 
effect would appear only in the stationary phase of the culture growth. But antimicrobial activity was also detected in the exponential growth phase of the strain 1350R2-TSA30-6. We have concluded that other volatile compounds, identified in an active fraction of this strain, were responsible for this early effect. For example, antibacterial, antiviral, or antifungal activities were previously reported for 1,2-benzenedicarboxylic acid, diisooctyl ester (Rameshthangam \& Ramasamy, 2007; Maruthupandian \& Mohan, 2011) and 1,3-dimethyl-benzene (El-Shouny et al., 2014). Some compounds (ethylbenzene, $p$-xylene) were previously identified in mixtures of bacterial volatiles (TenorioSalgado et al., 2013), while others (cyclohexanone) - in plant extracts (Kim et al., 2011) possessing antimicrobial activity.

GC-MS results for the strain 1410WF1-TSA30-2 markedly differed from the results for strain 1350R2TSA30-6. The only common antimicrobial compound was 1,2-benzenedicarboxylic acid, diisooctyl ester. Cyclic dipeptides were not found, but a range of other compounds with different bioactivities were identified. Antibacterial, antiviral, antifungal, or antioxidant activities were previously reported for dibutyl phthalate (Maruthupandian \& Mohan, 2011), nonadecane (Fernando et al., 2005), phenol, 2,4-bis(1,1dimethylethyl)- (Varsha et al., 2015). Some compounds (hexadecane, octadecane) were previously identified in antimicrobial or nematicidal mixtures of bacterial volatiles (Gu et al., 2007; Karanja et al., 2010), while others (1-nonadecene, 2-methyl-eicosane) - in plant extracts with antibacterial activity (Boussaada et al., 2008). The main compounds in antibacterial mixture of volatiles of the strain 1410WF1-TSA30-2 were benzoic acid, octadecyl ester and 1,2-benzenedicarboxylic acid, bis(2-methylpropyl) ester. We could not find any information about putative antimicrobial activity of octadecyl benzoate; it was not listed among bacterial volatiles in the $\mathrm{mVOC}$ and SuperScent databases either. But the esters of 1,2-benzenedicarboxylic acid (bis(2ethylhexyl) ester, bis(2-methylpropyl) ester, butyl-2methylpropyl ester, butyl-2-ethylhexyl ester, diisooctyl ester, etc.) are frequently the main components of antibacterial and antifungal mixtures of volatiles from different sources: algae (Sivakumar, 2014), plants (Joshi et al., 2011), fungi (Nakalembe \& Kabasa, 2012), bacteria (El-Mehalawy et al., 2008). Actually these esters are believed to be responsible for antimicrobial activity of these mixtures of volatiles. Antiviral, antifungal, and antibacterial activities were demonstrated for 1,2-benzenedicarboxylic acid, bis(2-ethylhexyl) ester; while antimicrobial, antioxidant, and antitumor activities were shown for 1,2-benzenedicarboxylic acid, mono(2-ethylhexyl) ester (Kavitha et al., 2009; Karthikeyan et al., 2014). Antibacterial and antifungal activities were confirmed for 1,2-benzenedicarboxylic acid, bis(5-ethylheptyl) ester (Kavitha et al., 2009). 1,2-benzenedicarboxylic acid, bis(2-methylpropyl) ester, found in active antibacterial fraction of the strain 1410WF1-TSA30-2, had been also identified in a few other representatives of the genus Bacillus (Hao \& Lu, 2007; Mallaiah \& Muthamilan, 2015).

It is known that bacteria use volatile metabolites for inter- and intraspecific communications as well as in order to respond and adapt to environmental changes (Audrain et al., 2015). Microorganisms in caves form multispecies communities with complex interaction networks among their members, and bacterial volatile mixtures can participate in these interactions. For example, it had been previously shown that Bacillus sp. can start producing cyclic dipeptides when challenged by a co-culture of other Bacillus species (de Carvalho \& Abraham, 2012). Our results showed that antimicrobial volatile mixtures of strains 1350R2TSA30-6 and 1410WF1-TSA30-2 could be also involved in the competition and engagement with other bacterial species in Krubera-Voronja Cave. The strains of Grampositive genera Paenibacillus and Brevibacillus (phylum Firmicutes, family Paenibacillaceae) were sensitive to active antimicrobial fractions of both strains isolated from the same cave. The main difference between volatiles of both investigated strains was in their antagonism against actinobacterial strain of the genus Streptomyces. It is interesting that antimicrobial compounds of the strain 1410WF1-TSA30-2 were antagonistic against bigger number of cave strains than antimicrobial compounds of the strain 1350R2TSA30-6. This is contrary to the zero antimicrobial activity of volatiles of the strain 1410WF1-TSA30-2 against pathogenic bacteria. It was supposed that the primary role of volatiles of the strain 1410WF1TSA30-2 is the competition with the indigenous Grampositive microorganisms of the cave.

In conclusion, our results clearly demonstrated that while screening for novel bioactive compounds, examining the lesser-studied phyla, such as Firmicutes, rather than the commonly examined Actinobacteria is an important and promising approach. Cave actinobacteria are usually the main targets of bioactivity assays, and therefore the antimicrobial potential of other bacteria is underestimated. Detailed analysis of two Firmicutes strains, isolated from Krubera-Voronja Cave, revealed two different mixtures of compounds with antibacterial activity. The main antibacterial compounds of the strain 1350R2-TSA30-6 were pyrrolopyrazines, and the main antibacterial compound of the strain 1410WF1-TSA30-2 was bis(2methylpropyl) ester of 1,2-benzenedicarboxylic acid. To the best of our knowledge, our study is the first report on chemical characterization of antimicrobial mixtures of Firmicutes isolated from caves.

\section{ACKNOWLEDGEMENT}

This work was supported by the Research Council of Lithuania (grant No. MIP-005/2014) and the National Geographic's Global Exploration Fund (grant No. GEFNE50-Y12).

\section{REFERENCES}

Attimarad S.L., Ediga G.N., Karigar A.A., Karadi R., Chandrashekhar N. \& Shivanna C., 2012 - Screening, isolation and purification of antibacterial agents from marine actinomycetes. International Current Pharmaceutical Journal, 1: 394-402.

http://dx.doi.org/10.3329/icpj.v1i12.12448 
Audrain B., Farag M., Ryu C.-M. \& Ghigo J.-M., 2015 Role of bacterial volatile compounds in bacterial biology. FEMS Microbiology Reviews, 39: 222-233. http://dx.doi.org/10.1093/femsre/fuu013

Blair J.M.A., Webber M.A., Baylay A.J., Ogbolu D.O. \& Piddock L.J.V., 2015 - Molecular mechanisms of antibiotic resistance. Nature Reviews Microbiology, 13: 42-51. http://dx.doi.org/10.1038/nrmicro3380

Boussaada O., Ammar S., Saidana D., Chriaa J., Chraif I., Daami M., Helal A.N. \& Mighri Z., 2008 Chemical composition and antimicrobial activity of volatile components from capitula and aerial parts of Rhaponticum acaule DC growing wild in Tunisia. Microbiological Research, 163: 87-95. http://dx.doi.org/10.1016/j.micres.2007.02.010

Cheeptham N., Sadoway T., Rule D., Watson K., Moote P., Soliman L.C., Azad N., Donkor K.K. \& Horne D., 2013 - Cure from the cave: volcanic cave actinomycetes and their potential in drug discovery. International Journal of Speleology, 42: 35-47.

http://dx.doi.org/10.5038/1827-806X.42.1.5

Choma I.M. \& Grzelak E.M., 2011 - Bioautography detection in thin-layer chromatography. Journal of Chromatography A, 1218: 2684-2691.

http://dx.doi.org/10.1016/j.chroma.2010.12.069

de Carvalho M.P. \& Abraham W.-R., 2012 - Antimicrobial and biofilm inhibiting diketopiperazines. Current Medicinal Chemistry, 19: 3564-3577.

http://dx.doi.org/10.2174/092986712801323243

Dunkel M., Schmidt U., Struck S., Berger L., Gruening B., Hossbach J., Jaeger I.S., Effmert U., Piechulla B., Eriksson R., KnudsenJ. \& Preissner R., 2009 SuperScent - a database of flavors and scents. Nucleic Acids Research, 37: D291-D294.

http://dx.doi.org/10.1093/nar/gkn695

El-Mehalawy A.A., Gebreel H.M., Rifaat H.M., El-Kholy I.M. \& Humid A.A., 2008-Effect of antifungal compounds produced by certain bacteria on physiological activities of human- and plant- pathogenic fungi. Journal of Applied Sciences Research, 4: 425-432.

El-Shouny W.A.E., El-Zaher E.H.F.A., Khalil M.A.E. \& El-Salam O.A., 2014 - Antimicrobial activity of chamomile acetone extract against some experimentallyinduced skin infections in mice. Egyptian Journal of Environmental Research, 2: 58-70.

Fernando W.G.D., Ramarathnam R., Krishnamoorthy A.S. \& Savchuk S.C., 2005 - Identification and use of potential bacterial organic antifungal volatiles in biocontrol. Soil Biology and Biochemistry, 37: 955-964. http://dx.doi.org/10.1016/j.soilbio.2004.10.021

Gabriel C.R \& Northup D.E., 2013 - Microbial ecology: caves as an extreme habitat. In: Cheeptham N. (Ed.), Cave microbiomes: a novel resource for drug discovery. SpringerBriefs in Microbiology, 1: 85-108.

http://dx.doi.org/10.1007/978-1-4614-5206-5 5

Gu Y.-Q., Mo M.-H., Zhou J.-P., Zou C.-S. \& Zhang K.-Q., 2007 - Evaluation and identification of potential organic nematicidal volatiles from soil bacteria. Soil Biology and Biochemistry, 39: 2567-2575.

http://dx.doi.org/10.1016/j.soilbio.2007.05.011

Hao R. \& Lu A., 2007 - Conversion and degradation of crude oil by Bacillus SP3. Chinese Journal of Geochemistry, 26: 201-206.

http://dx.doi.org/10.1007/s11631-007-0201-9

Herold K., Gollmick F.A., Groth I., Roth M., Menzel K.-D., Möllmann U., Gräfe U. \& Hertweck C., 2005 Cervimycin A-D: a polyketide glycoside complex from a cave bacterium can defeat vancomycin resistance. Chemistry: a European Journal, 11: 5523-5530.

http://dx.doi.org/10.1002/chem.200500320
Hodges T.W., Slattery M. \& Olson J.B., 2012 - Unique actinomycetes from marine caves and coral reef sediments provide novel PKS and NRPS biosynthetic gene clusters. Marine Biotechnology, 14: 270-280. http://dx.doi.org/10.1007/s10126-011-9410-7

Joshi S., Mishra D., Bisht G. \& Khetwala K.S., 2011 Essential oil composition and antimicrobial activity of Lobelia pyramidalis wall. EXCLI Journal, 10: 274-279.

Karanja E., Boga H., Muigai A., Wamunyokoli F., Kinyua J. \& Nonoh J., 2010 - Growth characteristics and production of secondary metabolites from selected novel Streptomyces species isolated from selected Kenyan national parks. In: Proceedings of the $5^{\text {th }}$ JKUAT Scientific, Technological and Industrialization Conference, Juja, 51-80.

Karthikeyan S.C., Velmurugan S., Donio M.B.S., Michaelbabu M. \& Citarasu T., 2014 - Studies on the antimicrobial potential and structural characterization of fatty acids extracted from Sydney rock oyster Saccostrea glomerata. Annals of Clinical Microbiology and Antimicrobials, 13: 332.

http://dx.doi.org/10.1186/s12941-014-0057-x

Kavitha A., Prabhakar P., Vijayalakshmi M. \& Venkateswarlu Y., 2009 - Production of bioactive metabolites by Nocardia levis $M K-V L \_113$. Letters in Applied Microbiology, 49: 484-490.

http://dx.doi.org/10.1111/j.1472-765X.2009.02697.x

Kieraite-Aleksandrova I., Aleksandrovas V. \& Kuisiene N., 2015 - Down into the Earth: microbial diversity of the deepest cave of the World. Biologia, 70: 989-1002. http://dx.doi.org/10.1515/biolog-2015-0127

Kim W.J., Hwang K.-H., Park D.-G., Kim T.-J., Kim D.-W., Choi D.-K., Moon W.-K. \& Lee K.-H., 2011 - Major constituents and antimicrobial activity of Korean herb Acorus calamus. Natural Product Research, 25: 1278-1281. http:/ /dx.doi.org/10.1080/14786419.2010.513333

Kuisiene N., Jomantiene R., Valiunas D. \& Chitavichius D., 2002 - Characterization of thermophilic proteolytic spore-forming bacteria from a geothermal site in Lithuania based on 16S rDNA RFLP and ITS-PCR analyses. Microbiology, 71: 712-716.

http://dx.doi.org/10.1023/A:1021440208887

Kumar S.N., Lankalapalli R.S \& Kumar B.S., 2014 - In vitro antibacterial screening of six proline-based cyclic dipeptides in combination with $\beta$-lactam antibiotics against medically important bacteria. Applied Biochemistry and Biotechnology, 173: 116-128. http://dx.doi.org/10.1007/s12010-014-0808-3

Lamprinou V., Tryfinopoulou K., Velonakis E.N., Vatopoulos A., Antonopoulou S., Fragopoulou E., Pantazidou A. \& Economou-Amilli A., 2015 Cave cyanobacteria showing antibacterial activity. International Journal of Speleology, 44: 231-238. http:/ / dx.doi.org/10.5038/1827-806X.44.3.2

Lemfack M.C., Nickel J., Dunkel M., Preissner R. \& Piechulla B., 2014 - mVOC: a database of microbial volatiles. Nucleic Acids Research, 42: D744-D748. http://dx.doi.org/10.1093/nar/gkt1250

Leyton J., Borquez J., Darias J., Cueto M., Díaz-Marrero A.R. \& Riquelme C., 2012 - Diketopiperazines produced by an Bacillus species inhibits Vibrio parahaemolyticus. Journal of Aquaculture Research \& Development, 3: 144. http://dx.doi.org/10.4172/2155-9546.1000144

Ludwig W., Strunk O., Westram R., Richter L., Meier H., Yadhukumar, Buchner A., Lai T., Steppi S., Jobb G., Förster W., Brettske I., Gerber S., Ginhart A.W., Gross O., Grumann S., Hermann S., Jost R., König A., Liss T., Lüßmann R., May M., Nonhoff B., Reichel B., Strehlow R., Stamatakis A., Stuckmann N., Vilbig A., Lenke M., Ludwig T., Bode A. \& Schleifer K.-H., 2004 - ARB: a software environment for sequence data. Nucleic Acids Research, 32:1363-1371. http://dx.doi.org/10.1093/nar/gkh293 
Mallaiah B. \& Muthamilan M., 2015 - Isolation and identification of antifungal compounds from Bacillus subtilis inhibiting the growth of Fusarium incarnatum (Desm.) Sacc. incitant of crossandra wilt. International Journal of Tropical Agriculture, 33: 1691-1696.

Maruthupandian A. \& Mohan V.R., 2011 - GC-MS analysis of some bioactive constituents of Pterocarpus marsupium Roxb. International Journal of ChemTech Research, 3: 1652-1657.

Mondol M.A., Tareq F.S., Kim J.H., Lee M., Lee H.S., Lee Y.J., Lee J.S. \& Shin H.J., 2011 - Cyclic ethercontaining macrolactins, antimicrobial 24-membered isomeric macrolactones from a marine Bacillus $s p$. Journal of Natural Products, 74: 2582-2587. http://dx.doi.org/10.1021/np200487k

Montano E.T. \& Henderson L.O., 2013 - Studies of antibiotic production by cave bacteria. In: Cheeptham N. (Ed.), Cave microbiomes: a novel resource for drug discovery. SpringerBriefs in Microbiology, 1: 109-130. http://dx.doi.org/10.1007/978-1-4614-5206-5_6

Moushumi Priya A. \& Jayachandran S., 2012 - Induction of apoptosis and cell cycle arrest by bis (2-ethylhexyl) phthalate produced by marine Bacillus pumilus MB 40. Chemico-Biological Interactions, 195: 133-143. http://dx.doi.org/10.1016/j.cbi.2011.11.005

Nakaew N., Pathom-aree W. \& Lumyong S., 2009 - First record of the isolation, identification and biological activity of a new strain of Spirillospora albida from Thai Cave soil. Actinomycetologica, 23: 1-7. http://doi.org/10.3209/saj.SAJ230102

Nakaew N., Sungthong R., Yokota A. \& Lumyong S., 2012 - Nonomuraea monospora sp. nov., an actinomycete isolated from cave soil in Thailand, and emended description of the genus Nonomuraea. International Journal of Evolutionary and Systematic Microbiology, 62: 3007-3012. http://dx.doi.org/10.1099/ijs.0.035220-0

Nakalembe I. \& Kabasa J.D., 2012 - Anti-microbial activity and biochemical constituents of two edible and medicinal mushrooms of Mid-Western, Uganda. Research Journal of Pharmacology, 6: 4-11. http://dx.doi.org/10.3923/rjpharm.2012.4.11

Nimaichand S., Devi A.M., Tamreihao K., Ningthoujam D.S. \& Li W.-J., 2015 - Actinobacterial diversity in limestone deposit sites in Hundung, Manipur (India) and their antimicrobial activities. Frontiers in Microbiology, 6: 413. http://dx.doi.org/10.3389/fmicb.2015.00413

Pandey A., Naik M. \& Dubey S.K., 2010 - Hemolysin, protease, and EPS producing pathogenic Aeromonas hydrophila strain An4 shows antibacterial activity against marine bacterial fish pathogens. Journal of Marine Biology, ID 563205.

http://dx.doi.org/10.1155/2010/563205

Pérez-Picaso L., Escalante J., Olivo H.F. \& Rios M.Y., 2009 - Efficient microwave assisted syntheses of 2,5-diketopiperazines in aqueous media. Molecules, 14: $2836-2849$.

http://dx.doi.org/10.3390/molecules 14082836

Rajput Y., Biswas J. \& Rai V., 2012 - Potentiality test in antimicrobial activity and antibiotic sensitivity of subterranean Streptomyces strains isolated from Kotumsar Cave of India. International Journal of Biological Chemistry, 6: 53-60.

http://dx.doi.org/10.3923/ijbc.2012.53.60

Rameshthangam R. \& Ramasamy P., 2007 - Antiviral activity of bis(2-methylheptyl)phthalate isolated from Pongamia pinnata leaves against White Spot Syndrome Virus of Penaeus monodon Fabricius. Virus Research, 126: 38-44.

http://dx.doi.org/10.1016/j.virusres.2007.01.014
Rice L.B., 2006 - Antimicrobial resistance in Grampositive bacteria. The American Journal of Medicine, 119: S11-S19.

http://dx.doi.org/10.1016/j.amjmed.2006.03.012

Rossolini G.M., Arena F. \& Pollini S., 2014 - Novel infectious diseases and emerging Gram-positive multi-resistant pathogens in hospital and community acquired infections. In: Marinelli F. \& Genilloud O. (Eds.), Antimicrobials - new and old molecules in the fight against multi-resistant bacteria. Springer-Verlag Berlin Heidelberg, p. 11-28.

http://dx.doi.org/10.1007/978-3-642-39968-8 2

Rule D. \& Cheeptham N., 2013 - The effects of UV light on the antimicrobial activities of cave actinomycetes. International Journal of Speleology, 42: 147-153. http://dx.doi.org/10.5038/1827-806X.42.2.7

Sanchez S. \& Demain A.L., 2008 - Metabolic regulation and overproduction of primary metabolites. Microbial Biotechnology, 1: 283-319.

http://dx.doi.org/10.1111/j.1751-7915.2007.00015.x

Sanghvi G.V., Ghevariya D., Gosai S., Langa R., Dhaduk N., Kunjadia P.D., Vaishnav D.J. \& Dave G.S., 2014 Isolation and partial purification of erythromycin from alkaliphilic Streptomyces werraensis isolated from Rajkot, India. Biotechnology Reports, 1-2: 2-7.

http://dx.doi.org/10.1016/j.btre.2014.05.003

Sendra A. \& Reboleira A.S.P.S., 2012 - The world's deepest subterranean community - Krubera-Voronja Cave (Western Caucasus). International Journal of Speleology, 41: 221-230.

http://dx.doi.org/10.5038/1827-806X.41.2.9

Sivakumar S.R., 2014 - GC-MS analysis and antibacterial potential of white crystalline solid from red algae Portieria hornemannii against the plant pathogenic bacteria Xanthomonas axonopodis pv. citri (Hasse) Vauterin et al. and Xanthomonas campestris pv. malvacearum (Smith 1901) dye 1978b. International Journal of Advanced Research, 2: 174-183.

Sumi C.D., Yang B.W., Yeo I.C. \& Hahm Y.T., 2015 Antimicrobial peptides of the genus Bacillus: a new era for antibiotics. Canadian Journal of Microbiology, 61: 93-103.

http://dx.doi.org/10.1139/cjm-2014-0613

Tareq F.S., Kim J.H., Lee M.A., Lee H.S., Lee J.S., Lee Y.J. \& Shin H.J., 2013 - Antimicrobial gageomacrolactins characterized from the fermentation of the marinederived bacterium Bacillus subtilis under optimum growth conditions. Journal of Agricultural and Food Chemistry, 61: 3428-3434.

http://dx.doi.org/10.1021/jf4009229

Tenorio-Salgado S., Tinoco R., Vazquez-Duhalt R., Caballero-Mellado J. \& Perez-Rueda E., 2013 Identification of volatile compounds produced by the bacterium Burkholderia tropica that inhibit the growth of fungal pathogens. Bioengineered, 4: 236-243. http://dx.doi.org/10.4161/bioe. 23808

Tomova I., Lazarkevich I., Tomova A., Kambourova M. \& Vasileva-Tonkova E., 2013 - Diversity and biosynthetic potential of culturable aerobic heterotrophic bacteria isolated from Magura Cave, Bulgaria. International Journal of Speleology, 42: 65-76. http://dx.doi.org/10.5038/1827-806X.42.1.8

Varsha K.K., Devendra L., Shilpa G., Priya S., Pandey A. \& Nampoothiri K.M., 2015 - 2,4-Di-tert-butyl phenol as the antifungal, antioxidant bioactive purified from a newly isolated Lactococcus $s p$. International Journal of Food Microbiology, 211: 44-50.

http://dx.doi.org/10.1016/j.ijfoodmicro.2015.06.025 
Wright P.M., Seiple I.B. \& Myers A.G., 2014 - The evolving role of chemical synthesis in antibacterial drug discovery. Angewandte Chemie International Edition, 18: $8840-8869$.

http://dx.doi.org/10.1002/anie. 201310843
Yan P.-S., Song Y., Sakuno E., Nakajima H., Nakagawa H. \& Yabe K., 2004 - Cyclo (L-Leucyl-L-Prolyl) produced by Achromobacter xylosoxidans inhibits aflatoxin production by Aspergillus parasiticus. Applied and Environmental Microbiology, 70: 7466-7473.

http://dx.doi.org/10.1128/AEM.70.12.7466-7473.2004 